Research Article

\title{
Meeting the Nutritional Needs for the Children: The Role of Fish Products from the Emerging Aquaculture of Nepal
}

\author{
Sudha Sapkota $^{1 *}$, Sumitra Laudari ${ }^{2}$, Shubha Devi Sapkota ${ }^{3}$ \\ ${ }^{1}$ Monitoring \& Evaluation Division, Nepal Agricultural Research Council, Nepal, \\ ${ }^{2}$ Directorate of Fisheries Development, Nepal, \\ ${ }^{3}$ Department of Nursing, NPI - Narayani Samudayik Hospital, Nepal
}

Article Information
Received: 24 January 2020
Revised version received: 31 August 2020
Accepted: 07 September 2020
Published: 29 October 2020
Cite this article as:
S. Sapkota et al. $(2020)$ Int. J. Soc. Sc. Manage. 7(4):
198-201. DOI: $10.3126 /$ ijssm.v7i4.32469
*Corresponding author
Sudha Sapkota,
Monitoring \& Evaluation Division, Nepal
Agricultural Research Council, Nepal
Email: sudhanepal@ gmail.com
Peer reviewed under authority of IJSSM
C) 2020 IJSSM, Permits unrestricted use under the
CC-By-NC license.
OPEN 9 ACCESS
This is an open access article \& it is licensed under a
(https://creativecommons.org/licenses/by-nc/4.0/)
Keywords: Children; Fishery; Nutrition; Nepal

Keywords: Children; Fishery; Nutrition; Nepal

\begin{abstract}
Contributions of fish diet in the daily lifestyles for nutritional security of children are examined through trend analysis and individual questionnaire provided to the caretaker of children's group of 5 to 13 years, to address the issues of fish dishes, preferences, and nutritional awareness. The per capita fish consumption per person in Nepal is about $3.36 \mathrm{~kg}$ as compared to the world $19 \mathrm{~kg}$ and least developing countries $11 \mathrm{~kg}$. The pond aquaculture was most prominently carried with $95.5 \%$ pond area located where $2.48 \%$ in hills and only $0.39 \%$ in the mountain. People's preference for dishes is also one of the major factors to determine the choice for the fish variety as a commodity. Among different dishes, fried fish (91.2\%), fish pakauda $(50 \%)$, fish gravy $(41.4 \%)$ were the three most preferred for the children of the age group of 5 to 13 . Multiple regressions were run to find out the significance level of difference in nutrient availability among the prepared dishes. Rainbow trout, Tilapia, and Pangasius are the emerging fish species and the nutrient levels of cooked fish may vary; therefore, protein and calcium level of cooked fish's proximate analysis was done. This showed that the protein content of Tilapia was low compared to cooked Trout and Pangasius, however, the level of calcium was higher in Tilapia than the Trout and Pangasius. The occurrence of a thin spine in the food was the major problem for the children, therefore, to increase fish consumption whole fish meat paste milling machine is recommended.
\end{abstract}

\section{Introduction}

Nepal being a landlocked country to fulfill the aquaculture needs must depend on freshwater products. Approximately $5 \%$ of the total area of the country is known to be occupied by different freshwater aquatic habitats in the form of a river, lake, swamps, ponds, and rice fields which occupy 398,000ha (Directorate of Fisheries Development [DoFD],
2017). Although Nepal's aquatic resources are limited to inland fishery production the presence of 232 indigenous fish species depicted the richness in aquatic biodiversity and shows the abundance opportunities (Shrestha, 2008). Out of such an area, Nepal's total production of fish is $83897 \mathrm{mt}$ in the year 2017 (DoFD, 2017). These figures point out the 
increasing trend, awareness, and interest of peoples about the importance of fishery. An increase in a product is a triggering factor for the outlet of the product. Increased fish production needs fish to be consumed, because of population increase, and increasing per capita consumption among certain sectors (driven by the health benefits of consuming fish) will have to be provided primarily through aquaculture. Besides this several health benefits $\omega-3$ or N-3 fatty acids, protein, amino acids, folic acids and vitamins found in fish food to all age groups (Gurung, 2016; Limbu et al., 2012) have been reported. A study was done in Malawi also support the view that individuals fed intervention diets containing significantly more soft-boned fishes had lower incidences of anemia and common infections than those in the control group (Gibson et al., 2003). But history shows that the per capita fish consumption of Nepal has been ranked $144^{\text {th }}$ within the group of 160 countries in the year (Food and Agriculture Organization [FAO], 2018). For the increased rate of nutrition-balanced food intake; still, there is a gap in awareness and food intake habits. The study therefore designed to show the information regarding the preference of fish items by the children so that an intervention can be directed for increased nutritional availability for the children through aquaculture products.

\section{Objective}

- $\quad$ To depict the trend of fishery development and identify the fish intake level of the children and recommend ways for the increased nutritional level.

- $\quad$ To promote the intake of fish food in children's diet by creating enabling the fish product fits children's diet

\section{Methodology}

This study was conducted after the approval from the research committee of the Nepal Agricultural Research Council and presented in International Conference on Sustainable Fisheries \& Aquaculture Diversification. Written consent was obtained from each of the respondents. Participants' dignity was maintained by giving the right to reject or discontinue from the researcher study at any time. It comprises the two parts; a review of literature for the secondary data to depict the ecology wise scenario of fish production and the nutritional availability in the cooked food after proximate analysis. The second part of the study was based on the personal interview with the children for their interest in the fish product. The age range of 5 to 13 years of 100 children has been selected randomly and their caretakers were asked about the preference of fish dishes. Rainbow trout, Pangasius, and Tilapia were the three species of fishes selected and purposively reviewed the data about the proximate analysis.

Fat, protein fiber, calcium, magnesium, and phosphorus were the nutrients found after the proximate analysis in the cooked fish. Based on the basic requirement of protein and calcium intake for children and fish could be a means for the supplement. The study was purposively taken for the nutritional awareness of the children, therefore; only protein and the calcium content of the three fishes were done and found the $\mathrm{R}$ square value to compare the protein and calcium content. SPSS and Excel were the statistical packages to analyze the data.

\section{Result and Discussion}

The ecology wise scenario of fish production, the scenario of fish production, importance, and preference of fish food in children's diet have been summarized in the result and discussion part.

\section{Ecology Wise Scenario of Fish Production}

Fish species may differ in different water temperature and mineral content of water; also, the nutritional availability varies with the ecological segregation. Given, Table 1 shows the Terai ecological belt of the country with 9,488ha of the area has the highest area coverage $(95.5 \%)$. The scenario of fishpond culture shows that $95.5 \%$ of the area was shown in the Terai, $2.48 \%$ in hills whereas, only $0.39 \%$ of the pond fish culture has been found in the mountain.

\section{Fishery Production in Nepal}

The human population growth rate as well as the fish population growth rate is shown in Table 2. Fish population growth with a $10.8 \%$ increment is quite high shows the volume of production will be encouraging to search for a new niche for marketing through established a fish delivery network over the country.

Table 1: Scenario of Pond Fish Culture

\begin{tabular}{|l|l|l|l|l|l|}
\hline \hline Particulars & Pond (Nos.) & $\begin{array}{l}\text { Total } \\
\text { Area (ha) }\end{array}$ & $\begin{array}{l}\text { Fish Production } \\
\text { (Mt.) }\end{array}$ & Yield/Kg/ha & $\begin{array}{l}\text { Coverage } \\
\text { area (\%) }\end{array}$ \\
\hline \hline $\begin{array}{l}\text { A. Fish Production from } \\
\text { Aquaculture Practices }\end{array}$ & & & 55,500 & & \\
\hline A1 Pond Fish culture & 39,308 & 9,934 & 48,543 & 4,887 & \\
\hline Mountain & 154 & 11 & 28 & 2,545 & 0.39 \\
\hline Hill & 4,203 & 435 & 1,205 & 2,770 & 2.48 \\
\hline Terai & 34,951 & 9,488 & 47,310 & 4,986 & 95.5 \\
\hline
\end{tabular}

Source: Annual book, DoFD 2017. 
Table 2. Scenario of Fishery Production of Nepal

\begin{tabular}{|l|l|l|l|l|l|}
\hline Year & $\begin{array}{l}\text { Total } \\
\text { population }\end{array}$ & $\begin{array}{l}\text { Population } \\
\text { growth rate }\end{array}$ & $\begin{array}{l}\text { Total fish } \\
\text { production }\end{array}$ & $\begin{array}{l}\text { Total fish } \\
\text { growth }\end{array}$ & $\begin{array}{l}\text { Contribution of fish on } \\
\text { AGDP }\end{array}$ \\
\hline 2014 & & & 57520 & 14.3 & 2.71 \\
\hline 2015 & $28,656,282$ & 1 & 65770 & 5.7 & 4.9 \\
\hline 2016 & $28,982,771$ & 1.10 & 69500 & 10.8 & 6.31 \\
\hline 2017 & $29,304,998$ & 1.08 & 77000 & & 11.8 \\
\hline
\end{tabular}

Source: Annual book, DoFD 2017.

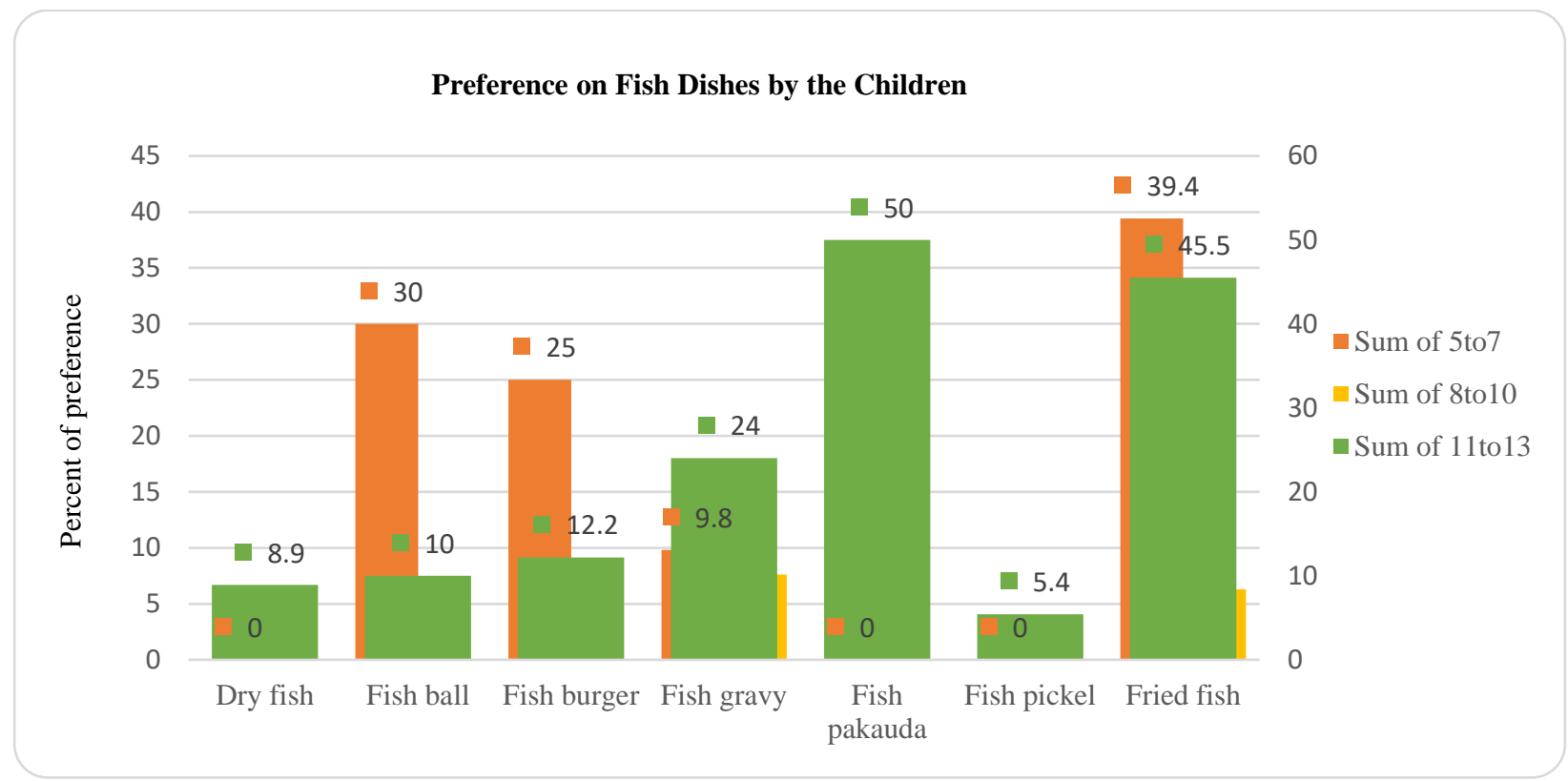

Fig. 1: Fish Dish Preference by the Children of Age Group of 5 to 13

\section{Importance of Fish Food in Child's Food}

Nutrition level and the mode of consumption is always a buzz in most of the part of Nepal where live fish is not easily accessible. How we could include fish food in children's food is a common question raised inside the parents who hadn't included fish food during their childhood. It has been reported that nearly all fish contain trace amounts of methyl mercury, an environmental contaminant. In large amounts, all forms of mercury are toxic to nerve cells and can cause vision problems. It creates controversy for the amount and the species of fish intake of the inland fishery for a low level of mercury level. The US Food and Drug Administration and Environmental Protection Agency advice serving 1 to 2-ounce servings of fish to children per week, beginning at age two. Fish lowest in mercury include Salmon and Tilapia (Wiesenberger, 2020). Fish is food for the brain as well as good protein, therefore; a small amount of fish could be beneficial for the significant change in the dietary requirement of amino acids and are the present very low amount in the vegetarian diet (FAO, 2018). Based on all the review and availability context study on the preference of cooked fish food of Trout, Pangasius, and Tilapia were taken.

\section{Children's Preference Regarding the Food Item}

Dry fish, fish ball, fish burger, fish gravy, fish pakauda, fish pickle, fried fish were the most preferred fish dishes reported by the respondents which are shown in Fig. 1. Among them, the most preferred dish by the age group of 5 to 7 was the fried fish $(39.4 \%)$ and the fishball $(30 \%)$. Preference of age group of 8 to 10 was fish gravy and fried fish whereas, the age group of 11 to 13 preferred fish pakauda $(50 \%)$ and fried fish $(45.5 \%)$. Among the respondents, $80 \%$ reported that the preference of children towards these kinds of fish dishes is due to less chance of spines in the dishes.

\section{Nutrition Availability on Three Different Fish Dishes}

Trout, Pangasius, and Tilapia were the three fish species used during fish dishes preparation. Tilapia tacos, blackened tilapia with butter carrots, garlicky grilled tilapia with couscous, ham wrapped tilapia, oriental rainbow trout, trout curry, deep-fried rainbow trout, smoked rainbow trout, steamed rainbow trout, easy lemon cheese baked pangasius, pangasius fillets in the light crust, Florentine pangasius fillets were the cooked dishes taken as a sample and done proximate analysis (Pradhan et. al., 2016). Among various nutrient value comes from proximate value only protein and calcium content of the dishes were calculated, and Table 3 
shows calcium content in tilapia was highly significant than trout and Pangasius species. Whereas, the protein content of trout was highly significant to the other two species of fish.

Table 3: Status of protein and calcium content of fish.

\begin{tabular}{|l|c|c|c|c|}
\hline $\begin{array}{l}\text { Variab } \\
\text { le }\end{array}$ & $\begin{array}{c}\text { Coefficien } \\
\text { ts }\end{array}$ & $\begin{array}{c}\text { Standard } \\
\text { Error }\end{array}$ & t Stat & $\begin{array}{c}P \text { - } \\
\text { value }\end{array}$ \\
\hline $\begin{array}{l}\text { Consta } \\
\text { nt }\end{array}$ & 11.531 & 5.174 & 2.228 & 0.049 \\
\hline Protein & 0.019 & 0.004 & 4.322 & 0.001 \\
\hline $\begin{array}{l}\text { Calciu } \\
\text { m }\end{array}$ & -7.198 & 6.27 & $\begin{array}{c}- \\
1.148\end{array}$ & 0.277 \\
\hline
\end{tabular}

Observation $=13 \mathrm{R}^{2}=0.653 \mathrm{~F}$ statistics $=9.4$

It is reported that a lower level of protein in the diet can retard the growth and development of babies and toddlers need to play and learn. Every cell in the body contains protein, it makes up enzymes needed for chemical reactions and 10 percent of a child's energy comes from protein. Dietary proteins are digested into amino acids that are used to make body proteins to grow and maintain the bones, muscles, blood, skin, hair, and organs. Of the 22 amino acids, babies and toddlers can make 13 and must get the others from protein-rich foods, such as breast milk, formula, meat, eggs, and fish. Tilapia fish is considered a fatty fish and is different research has proved that fatty fish contain a high level of Omega-3 fats and less mercury content (Weisenberger, 2020). Omega 3 fatty acids are healthy fats that lower inflammation and blood triglycerides. They have also been associated with a reduced risk of heart disease. Nepal, one of the poorest nations in both ways due to slow economic growth and lack of marine product people suffers severe malnutrition problems, especially among young children. Tilapia, fish suitable for the Terai region which has a large pie in production have the possibility of profitable in small scale farmers as well as could provide cheap sources of protein, calcium, and omega -3 . Besides all those benefits precautionary measures should be followed during fish consumption for the reduction of stuck of spines on children.

\section{Recommendation}

- Develop a plan to incorporate fish food into school children's diets.

- Make aware to a fish processor to develop fish product without the fish bones by introducing crushing fish to a paste whole fish meat paste milling machine.

\section{Conflict of Interest}

Authors declares no conflict of interest with the present publication.

\section{Acknowledgment}

The authors would like to acknowledge our sincere thanks to Dr. Tek Bahadur Gurung and Nita Pradhan for their help and support.

\section{References}

DoFD (2017) Directorate of Fisheries Development, Ministry of Agricultural, Land Management and Cooperatives, Department of Agriculture, Directorate of Fishery Development, Balaju, Nepal. Available at http://nefis.org.np/wp-content/uploads/2018/10/NJAFVol-34-20162017.pdf

FAO (2018) The State of World Fisheries and Aquaculture, Food and Agriculture Organization of the United Nations. Retrieved from http://www.fao.org/3/i9540en/i9540en.pdf

Gibson RS, Yeudall F, Drost N, Mtitimuni BM and Cullinan TR (2003) Experiences of a community-based dietary intervention to enhance micronutrient adequacy of diets low in animal source foods and high in phytate: a case study in rural Malawian children. The Journal of nutrition, 133 (11 Suppl 2): 3992S-3999S. DOI: https://doi.org/10.1093/jn/133.11.3992S Available at https://pubmed.ncbi.nlm.nih.gov/14672301/

Gurung TB (2016) Role of inland fishery and aquaculture for food and nutrition security in Nepal. Agriculture and food security 5(18): 1-9. DOI: https://doi.org/10.1186/s40066$\underline{016-0063-7}$

Limbu KP, Subba BR and Rai BK (2012) Nutritional status of three species of Molluscs in Nepal. In: Gupta VK, Verma AK and Singh GD (Eds) Perspectives in animal ecology and reproduction. Chapter 10, Delhi, 232-9.

Pradhan NA, Aryal GR and Wagle SK (2016) Pangasius Fish Dishes Cooking Method. Fisheries Research Division, NARC.

Shrestha TK (2008) Ichthyology of Nepal. A study of fishes of the Himalayan waters. Himalayan Ecosphere.

Weisenberger J (2020) Fish Healthy for my child? Eat Right Academy of nutrition and dietetic. Retrieved from https://www.eatright.org/food/nutrition/dietaryguidelines-and-myplate/is-fish-healthy-for-my-child 